\title{
Politics as Metis Ethnogenesis in Red River: Instrumental Ethnogenesis in the 1830s and 1840s in Red River
}

\author{
Rob Ferguson
}

This paper analyzes how the Metis of Red River began to emphasize their rights as British subjects as well as aboriginal descendents in the 1840s. This paper argues that the fusion of these two identities, into a single Metis one, was an attempt to further the economic rights of traders. Specifically, it was a legal argument so that the Metis elites of Red River could circumvent the Hudson's Bay Company's monopoly on buffalo and other trophy furs.

Gerhard Ens has theorized that Metis identity developed "instrumentally". The approach "sees ethnicity and the rise of nationalism as situational and strategic: a product of politics and the manipulation of resources by individuals and elites."1 This paper will analyze how the Metis began to emphasize their rights as British subjects as well as aboriginal descendants in the era following the merger of the Hudson's Bay Company (HBC) with the Northwest Company (NWC). The purpose of this paper is to argue that the notion of Metis identity as a combination of aboriginal rights and the rights of white settlers was a legal and political position taken by the principal Metis residents of Red River. This position was taken to gain commercial freedom from the Hudson's Bay Company so that they and the other residents could have a commercial future hunting buffalo and trophy furs.

This paper will analyze how the socio-economic environment of the north-west plains brought the residents of Red River into conflict with the Hudson's Bay Company. It will also analyze the reasons for the Hudson's Bay Company's strict interpretation of their charter to exclusive trade, and to analyze how that strict interpretation left the residents of Red River desperate. This paper will explain why the principal Metis settlers of Red River chose to portray themselves as dual citizens (British and Aboriginal) when they petitioned the Colonial Office to rescind the Company's charter in 1846, and how the timeline and structure of the legal argument was closely linked to the fortunes of the

\footnotetext{
${ }^{1}$ Gerhard Ens and Joe Sawchuk, From New Peoples to New Nations (Toronto: University of Toronto Press, 2016), p. 7.
} 
Metis elites. This paper argues that the articulation of Metis rights in the 1840s was a strategy to further the economic rights of Metis traders during this period.

\section{Red River Fur Trade after 1821}

The early part of the nineteenth century saw a significant re-orientation in the fur trade as practised by the Metis hunters in the Red River region. Previously, much of the fur trade had been in beaver pelts or other smaller fur bearing animals. The competition between the Northwest (NWC) and Hudson's Bay Companies (HBC) in the first two decades of the $19^{\text {th }}$ century created another and more significant marketplace for fur traders: the provisions (pemmican) trade. ${ }^{2}$ Pemmican was a staple food product created from a paste of dried buffalo meat mixed with grease. The combination of protein and fat was vital for those in the fur trade or living and working on the plains, as most of the game animals were quite lean in the area, not providing enough fat for long-term survival on the prairies. $^{3}$ The combination of protein and fat that pemmican provided was often the difference between life and death for these early explorers and traders. As the competition between the Hudson's Bay Company and Northwest Company accelerated, the provisions market rapidly expanded creating new opportunities for the hunters in the area. The competition caused the prices for these provisions to rapidly inflate, allowing those in the buffalo trade to become the most successful traders in the region. ${ }^{4}$ At the same time, much of the area in this vicinity had been trapped out and there was a dearth of fur bearing animals to rely on for trade. Accordingly, this new opportunity arose at a time when the Metis' previous livelihood was slowly evaporating.

After the merger of the two fur trade companies in 1821, the fur trade was drastically reorganized. The merger left many employees of both companies unemployed and seeking new opportunities. ${ }^{5}$ Many of the unemployed moved into Selkirk's settlement at Red River in the early 1820 s, bringing their mixed blood families with them. ${ }^{6}$ Although choosing to settle down in Red River, most of its mixed blood settlers still relied heavily on the provisions trade. However, the buffalo were moving further south and west from Red River, into hostile Sioux territory. ${ }^{7}$ The threat of the Sioux meant that small parties were vulnerable to attack. Hunting buffalo for a large community also meant that a common approach to herds was required, so that all returned with enough stock to sell

\footnotetext{
${ }^{2}$ George Colpitts, "Provisioning the HBC: Market Economies in the British Buffalo Commons in the Early Nineteenth Century," The Western Historical Quarterly Vol. 43 No.2, p. 185.

${ }^{3}$ Ibid.

${ }^{4}$ Ibid., 186.

${ }^{5}$ Gerhard Ens, Homeland to Hinterland (Toronto: University of Toronto Press, 1996), 8.

${ }^{6}$ Ens, 9.

${ }^{7}$ Colpitts, p186.
} 
and provisions to get through the winter. ${ }^{8}$ Therefore, the hunts had to become larger and more elaborate for protection and survival. ${ }^{9}$

There were three significant products that buffalo hunters hoped to trade after their hunts. The first significant product was pemmican, which was mostly sold to the HBC and was the primary economic motivation for the large scale buffalo hunt. ${ }^{10}$ The second significant product was tallow, which was used for making candles and soap. ${ }^{11}$ Although there was a small market for this in Red River, the most significant market was in London. As will be shown later, this required cooperation from the Hudson's Bay Company in order to sell. Usually it was sold to the $\mathrm{HBC}$, who would then sell it themselves in London. ${ }^{12}$ The third important product from the fur trade, and a very important one for this study, was the buffalo robe. Buffalo robes were becoming a very popular item in cities like Montreal and along the eastern seaboard in the United States. Despite the market for robes, the Hudson's Bay Company was not as significant a purchaser as the Americans due to different levels of efficiency in their transportation networks. $^{13}$

The merger of the two companies created a monopoly in Rupert's Land, ensuring that participants in the fur trade were entirely dependent on the whims of the Hudson's Bay Company for their livelihoods. The monopoly likely made conflict between the buffalo hunters of Red River and the HBC inevitable.

\section{Hudson's Bay Company after Union}

Most studies from this period in Red River ignore the inner business practices of the HBC, and thus the Company's actions to protect their monopoly can appear arbitrary or punitive. The reality is that their actions to protect the monopoly were entirely rational and not without justification, even if the result was detrimental to the economic growth of the Red River residents. This section will attempt to explain why the Company was so protective of its charter, so that the significant legal challenge in getting the Colonial Office to dismantle the monopoly can be understood, and help explain the background to the legal arguments the Red River residents pursued.

The period of competition between the NWC and the HBC was disastrous for the respective shareholders. In the century before the NWC began competing against the

\footnotetext{
${ }^{8}$ Ens, 39.

${ }^{9}$ Ibid.

${ }^{10}$ Colpitts, 181 .

${ }^{11}$ Ibid, 196.

${ }^{12}$ Ibid.

${ }^{13}$ Michael Hogue, Metis and The Medicine Line (Chapel Hill: University of North Carolina Press, 2015),
} 80. 
HBC for the plains fur trade, the Hudson's Bay Company paid dividends to its shareholders of between 5\% and $12 \%$ per annum, averaging 9\%. ${ }^{14}$ According to James Pelly, Governor of the HBC, "profits on the originally subscribed capital stock actually paid up of between 60 and $70 \%$ per annum from 1690 to $1800 . " 15$ This period of significant success ended when the NWC successfully challenged the HBC for their trade, resulting in a sharp drop in annual dividends paid to shareholders. Between 1800 and 1807 the dividends were reduced to $4 \%$, between 1808 and 1814 no dividends were paid out for the first time in its history, and between 1815 and the merger they once again only paid a dividend of $4 \% .{ }^{16}$ For shareholders that were accustomed to $9 \%$ dividends and enormous capital gains, these were shockingly poor returns. By adding the meagre returns to the bloodshed of the period, it was easy to see why the HBC was weary of competition and would do everything possible to prevent a similar state of affairs in the future.

As part of the terms of the merger with the Northwest Company, a 100\% call on capital for the stockholders of the two companies was required. ${ }^{17}$ Such an ambitious call on capital places pressure on a company to be very profitable very quickly. Fortunately, for the shareholders of the newly merged HBC, it was so. Until 1824, shareholders were once again receiving only $4 \%$ per annum as dividends, but the years between 1828 and 1837 were extremely profitable. This period saw dividends being paid twice annually at $5 \%$ each plus an additional annual bonus of between 6 and $10 \% .{ }^{18}$ The stockholders must have been pleased with their return, and the HBC bragged of its success to the Colonial Office. The Company would proceed to blame all of its previous ills on the competition which had come to a close. According to George Simpson:

"It will moreover be seen that animosities and feuds that kept the Indian Country in a state of continued disturbance, extending to the loss of lives and to the destruction of property, have, since 1821 entirely ceased; that the sale of spirituous liquors to the Indians has, in most parts of the country been entirely discontinued, and in all other parts so much reduced as to no longer be an evil; and that the moral and religious improvement of the native population has been greatly promoted."

He continues:

"The Indian Country, which, previous to the passing and granting of that Act and License (merger and monopoly) was a scene of violence and outrage.... All arising from the

\footnotetext{
${ }^{14}$ J.H. Pelly, Governor of HBC to Lords of Privy Council on Trade. 02/07/1838. Letter. Peel 210.

${ }^{15} \mathrm{Ibid}$.

${ }^{16}$ Ibid.

${ }^{17}$ Ibid.

${ }^{18}$ Ibid.
} 
violent competition existing among the traders. I have the satisfaction to say (The Indian Territory) has, since that period, been in a state of the most perfect tranquility. Beneficial as well to the Indian population as to the parties involved in the trade.",19

In 1835, the Company took over administration for the Red River Settlement. ${ }^{20}$ By this date, Red River had grown to five thousand residents and the cost of administration was substantial. The HBC believed that, with this added expense, the only way it could continue to turn a profit was by enforcing their charter right to exclusive trade. ${ }^{21}$ Part of their argument for the renewal of their charter in 1837 was that the administration of Red River was an expense that the Company was saving the British government, and therefore it was in the Empire's best interest for the Hudson's Bay Company to have a monopoly. ${ }^{22}$ The argument must have been persuasive as not only was the charter renewed, but the government began the process of ceding Vancouver Island to the Company.

The Company's monopoly had profound effects on the entire region's economy. Firstly, the monopoly prevented any British subjects from trafficking in fur, with one or two notable exceptions. ${ }^{23}$ Only the Company could purchase furs from the Indians or from British subjects, and was therefore in complete control of prices paid for goods. ${ }^{24}$ They were also the largest purchaser of pemmican and tallow, the implications of which will be discussed later. Significant tariffs were also charged on American goods coming into the settlement. ${ }^{25}$ Accordingly, the Company controlled the prices paid for all items and the prices for which they sold at. By being the only significant customer for provisions and tallow they were able to keep the prices for these goods artificially low, as well as pay whatever price they chose for furs. By subjecting all goods to significant tariffs entering from the United States, the HBC was able to ensure a healthy market for their own goods in Red River.

Clearly, the Company's monopoly ensured healthy annual returns for its shareholders, and that the Company was going to jealously guard its monopoly rights. Competition had been a harrowing experience for the company and it had no desire to endure it again.

${ }^{19}$ James Pelly, James Pelly to George Lord Glenley, Letter of 02/10/1837. (Quotation taken from George Simpson to James Pelly 02/01/1837). Peel 210.

${ }^{20}$ Ens, 32.

${ }^{21}$ James Pelly, Pelly to Privy Council on Trade, Letter of 02/07/1837. Peel 210.

${ }^{22}$ Ibid.

${ }^{23}$ Cuthbert Grant, James Sinclair, and Andrew McDermot were all initially given rights to traffic in furs, as long as nobody else did. This favouritism would last until the 1840s, when McDermot and Sinclair were accused of being complicit in the illegal trade with the Americans. Eventually, Sinclair and McDermot lost their preferential status.

${ }^{24}$ James E. Fitzgerald, An examination of the charter and proceedings of the Hudson's Bay Company, with reference to the grant of Vancouver's Island (London: Trelawney and Saunders, 1849), 211. Peel 262.

${ }^{25}$ Ibid. 
However, their heavy handedness in guarding the Company's monopoly rights would make enemies of the majority of Red River residents.

\section{Demographics of Red River after 1821}

There were two distinctive Metis communities at Red River: French south of the river, and the English north of the river at Fort Garry. ${ }^{26}$ The Catholic French were mostly former voyageurs and freemen who had trapped for the NWC. ${ }^{27}$ The English were usually former Anglican HBC employees. ${ }^{28}$ Where required, this paper shall use the commonly accepted differentiation of the two communities by using "metis" to refer to the French residents of Red River and "country born" for the English residents. ${ }^{29}$ Although they came from different backgrounds, spoke different languages, and had separate religions, the two communities would gain a unique sense of identity over several decades as their common interest in opposing the Hudson's Bay Company became apparent.

The Red River settlement swelled in size after those who were laid off by the merger of the two companies retired to Red River. ${ }^{30}$ Initially, this could have been a powder keg of discontent. The Pemmican Wars had created significant tensions on both sides, with the English Country Born volunteering to defend Selkirk's settlement from the Metis. ${ }^{31}$ However, as the relationship between the residents and the Company deteriorated, a certain solidarity between the two communities arose.

As mentioned, the main product of the fur trade had transitioned from beaver to buffalo by the time the two companies had merged. The value of a large hunting party was also discussed, leading to the annual hunts in Red River being composed of significant portions of the Metis and Country-Born communities. Significant cooperation was required from everyone during the hunt, so it is likely that many relationships were formed on these expeditions. It would have given them time to discuss common problems and potential strategies as well as to develop contacts. Considering the buffalo products were the most important economic good to both communities, their shared dependence on the HBC must have also been discussed. There is no doubt that, in the early years of Red River, the Country Born were significantly more loyal to the HBC than the Metis due to their history as HBC Factors, officers, and tradesmen. ${ }^{32}$ However, the shared

\footnotetext{
${ }^{26}$ Ens, 10 .

${ }^{27}$ Ibid.

${ }^{28}$ Ibid.

${ }^{29}$ Ens, 8.

${ }^{30}$ Ens, 10.

${ }^{31}$ Robertson Gladstone, The Hudson's Bay Company versus Magna Carta, and the British People (Liverpool, England: Financial Reform Association, 1857), 17. Peel 344.

${ }^{32}$ Ens, 53.
} 
dependence on buffalo brought the two communities together in opposition to the company. If one community had been more dependent on another industry for survival (agriculture for instance), then these relationships may have formed quite differently and the creation of a collective identity may never have occurred.

It was the desire of the Company that the residents of Red River become accomplished agriculturalists. ${ }^{33}$ The residents did not comply, as most of the residents were successful hunters and trappers, with no apparent desire to abandon their preferred method of earning a living as long as they still could do it. However, that does not mean that the residents of Red River were not interested in agriculture. As Gerhard Ens points out "The 1835 census shows, for example, that 80 of the 94 families in the parish of St. Andrews (Country-Born) cultivated at least one acre, and that in St. Francois Xavier (Metis) 76 of 97 families cultivated at least one acre." 34 W.L. Morton described the relationship between the buffalo hunt and agriculture as a 'fatal check' upon each other, and that "each depressed the price of the other's produce." 35 However, Gerhard Ens suggests that "subsistence agriculture and the buffalo hunt were more complementary than competitive. Whenever the hunt failed, the produce of the farm helped provide the needs of Metis hunters..." ${ }^{36}$ Ens is only discussing subsistence agriculture though, or families that were farming at least one acre, as opposed to families that were farming on a larger scale. Leland Clark has pointed out that the 1838 census shows significantly fewer families were farming at least ten acres of land, $17.7 \%$ of country-born families and only $2.3 \%$ of Metis families. ${ }^{37}$ Although there was a significant disparity between French and English families in 1838 , the gap tightened by 1849 where $28.2 \%$ of country-born families were farming at least ten acres and $20.7 \%$ of Metis families were. ${ }^{38}$ The notion that there was minimal agriculture in the Red River settlement is incorrect, as there was a significant amount of small scale subsistence farming and a little bit of larger scale farming. Not enough, though, for the community to rely on it as a staple.

Despite the prevalence of some agriculture in the settlement, it is reasonable to ask why there was not more of it? Most likely, it is that agriculture is difficult to learn and the initial attempts at it had failed. As Ens notes "Having grown up near trading posts in the

${ }^{33}$ J.H. Pelly, "Pelly's Report to Earl Grey" In Hudson's Bay Company (Red River Settlement), Copy of Memorial and Petitions from inhabitants of the Red River Settlement, complaining of the Government of the Hudson's Bay Company, and reports and correspondence on the subject of the memorial. April $24^{\text {th }}, 1847$. https://eclass.srv.ualberta.ca/pluginfile.php/2635068/mod_resource/content/1/1849-026015-p1 to120.pdf

${ }^{34}$ Ens, 38.

${ }^{35}$ Leland Clark, "The Place of the Metis within the agricultural economy of Red River during the 1840's and the 1850's," Canadian Journal of Native Studies (Volume 3, 1983), 70.

${ }^{36}$ Ens, 38 .

${ }^{37}$ Clark, 72 .

${ }^{38}$ Ibid. 
northwest, most were not only ill prepared to become farmers, but found the labour of clearing land for cultivation unpleasant." ${ }^{39}$ This was not the easiest environment to learn agriculture either as harsh winters, insects, droughts, and floods were commonplace causing even the most accomplished farmer to occasionally lose their crops. There was also the reality that, in the 1840 s, there was limited opportunity for a grain farmer in the region. ${ }^{40}$ The fur trade market was extremely limited, and without a railway to ship grain it was almost impossible to trade beyond the local market. ${ }^{41}$ The combination of difficult work, poor initial results, lack of opportunity and the desire to still hunt buffalo ensured that most residents would continue to rely on the buffalo hunt for their livelihoods.

By the 1830s and 1840s the Red River settlement was composed of two similar communities who both relied on the same resource for their livelihoods. Although there may have been some tensions between the two communities, for the most part they easily co-existed and both cooperated in the bi-annual buffalo hunts leading to lasting relationships between the Metis and Country-born communities. Both communities were active participants in subsistence agriculture but rarely farmed more than a couple of acres. The result was that both communities still relied heavily on their ability to sell buffalo products to the HBC.

\section{Conflict brews with the Hudson's Bay Company}

Conflict between the Red River residents and the Hudson's Bay Company became quite common after 1832, which was the first year the HBC was unwilling to purchase all of the trader's pemmican. ${ }^{42}$ The HBC had developed a regional purchasing system involving purchases from traders all over the plains, meaning that they were always able to meet their own needs even if there was a shortfall in one region. ${ }^{43}$ This crippled the collective bargaining power of the Red River residents. ${ }^{44}$ Prices paid for pemmican at Cumberland House (in modern eastern Saskatchewan) were only two to three pence ${ }^{45}$ per pound by 1833, whereas they had been nine pence per pound in $1823 .{ }^{46}$ Additionally, the fact the HBC was unwilling to purchase everyone's pemmican by 1832 , meant that many traders were not even getting these drastically reduced prices.

\footnotetext{
${ }^{39}$ Ens, 53.

${ }^{40}$ W.T. Easterbrook and Hugh Aitkin, Canadian Economic History (Toronto: University of Toronto Press, 1988), 343.

${ }^{41}$ Ibid.

${ }^{42}$ Colpitts, 193.

43 Ibid, 194.

44 Ibid.

45 The Hudson's Bay Company had changed their currency system from the previous Made Beaver (MB) to their sterling equivalents by this point. Colpitts, 188 .

${ }^{46}$ Ibid, 189.
} 
By the 1840s, the Company was harshly enforcing their exclusive rights of trade. They were able to impose arbitrary duties on American imports, and had imposed a $20 \%$ tariff on imports from Britain. ${ }^{47}$ Since the HBC also leased the land to the settlement's residents, they were enforcing a strict land deed by the 1840s as well. Settlers could forfeit their entire estate if they violated the Company's monopoly by trading in furs, peltry, or even dressing leather. ${ }^{48}$ The result was that the HBC could protect all aspects of its business from any competition.

As discussed earlier, one of the significant products derived from the buffalo hunt was buffalo core fat used to make tallow for soaps and candles. Tallow was usually rendered into one or two hundred pound parcels. ${ }^{49}$ The HBC was selling the tallow it purchased in Red River for triple the amount to shopkeepers in London. ${ }^{50}$ One of the most eminent merchants and residents of Red River was a country-born businessman named James Sinclair. Knowing what the prices of tallow were in London, he sent some tallow to be sold aboard one of the Company's ships from York Factory in 1843. Apparently, his venture did quite well and he attempted to replicate the feat the following year with a substantially larger amount of tallow. ${ }^{51}$ The HBC, however, refused to permit his tallow on the company ship leaving York Factory in 1844. This tallow sat in storage at York Factory until Sinclair agreed to sell it to the Company at their price point, two years later. ${ }^{52}$ By preventing Sinclair from trading in tallow, the Company ensured that one of the settlements most prominent members would actively support the free trade movement.

Resentment continued to develop amongst both Metis and Country-born communities when they began to feel discrimination by the company based on their mixed blood ancestry. The Company's officers were no longer being selected from the region, but were imported Highland Scots. ${ }^{53}$ They also became less likely to hire local trip-men and freighters for transport between York Factory and the settlement, as they began relying more on seasonal labour from overseas. ${ }^{54}$ The older residents, particularly those who were retired Company officers, resented these practices. As former officer James Bird said...

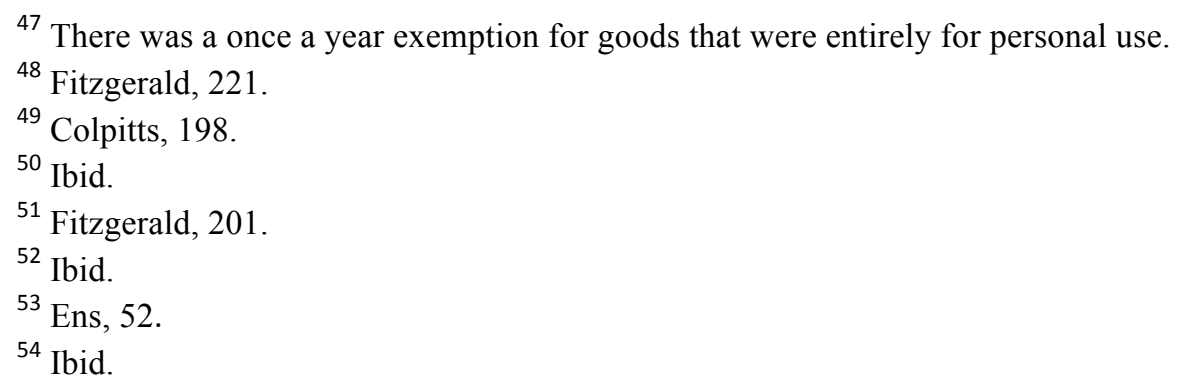


"I have now four sons at the house with me, the two oldest are now men fit for any duty in this part of the world but their (sic) is no opportunity for young people to push themselves forward in any way... they can hardly make a living. My two youngest sons have a better education than I had when came to this country, but it will be of no use to them. ${ }^{55}$

Residents, even affluent ones, were concerned that a lack of upward mobility in the company would leave their children destitute. Gerhard Ens comments "The Company provided employment for many male children of former employees but it offered no outlet for the ambitious... a trading career outside the company was the best alternative for young men. ${ }^{, 56}$ As the residents began to feel they or their children were handicapped by their mixed ancestry, the members of the two communities began to unite in opposition to the Company's practices.

By the mid 1840s, the Hudson's Bay Company had protected all aspects of its Rupert's Land business from competition. They dominated the market on goods sold in the settlement by applying significant tariffs to all goods procured from other sources. They prevented any residents from making money on export, by refusing to ship resident's goods overseas for sale and refusing to permit any non-company ship from landing at York Factory. This was exacerbated by the Company's refusal to promote local mixedblood residents into its Officer Corps and relying on more seasonal labour from overseas. The result was that residents began looking for ways to subvert the Company's licenses, especially when the opportunity arose south of the border in Pembina.

\section{The Arrival of the Americans}

The Hudson's Bay Company was not the only fur trading company operating in the northwest. The American market in the northwest was split between the American Fur Company (AFC) and the St. Louis Fur Company, who merged in 1842. The AFC was very familiar with competition with the Hudson's Bay Company, as they had competed viciously for control of furs in the Lake Superior and Rainy Lake regions, resulting in a secret agreement between the two company's principals George Simpson (HBC) and Ramsay Crooks (AFC) in $1833 .{ }^{57}$ The AFC agreed to cease their operation along the boundary and the $\mathrm{HBC}$ would pay them an annual subsidy. Part of the agreement was to

${ }^{55} \mathrm{Ibid}$.

${ }^{56}$ Ibid, 73.

${ }^{57}$ Ramsay Crooks had been in the fur trade a very long time, even being on the ill-fated overland Astoria expedition before the outbreak of the War of 1812. This expedition had attempted to set up a permanent American Fur Trading post at the mouth of the Columbia River in Oregon to compete with the British companies for furs in the west. His harrowing survival story became well known after Washington Irving's bestseller about the expedition was published in the 1830 s. 
ruthlessly crush any independent traders operating in their midst. ${ }^{58}$ This agreement was secret, however, and was probably unknown to the local actors.

In the late 1830s, the AFC wanted to expand the company's operations into northern Minnesota and to develop a larger presence on the upper Missouri River to collect buffalo robes. ${ }^{59}$ The Americans developed a market for buffalo robes that was never practical for the Hudson's Bay Company due to shipping costs. Additionally, there was a patriotic motivation for the AFC to expand in this region, as the buffalo that the Red River residents were hunting and selling to the $\mathrm{HBC}$ were being hunted in American territory. Accordingly, the Americans viewed the buffalo as their resource and wanted to prevent it being exploited by the foreign British. ${ }^{60}$ Part of that expansion included sending one of their fur traders, Norman Kittson, to set up posts (such as Pembina) along the border.

Pembina, now in North Dakota, was immediately south of the Red River settlement along the forty-ninth parallel. It was the largest of a series of small posts that Norman Kittson had set up just south of the border. As Clarence Rife explains:

"Kittson's policy was to set up a line of small posts at strategic points not far from the boundary and in some places not many miles from HBC centers. Thus he was better able to compete with his great adversary not only by preventing peltries taken on American territory from following the accustomed channels to the north, but by attracting furs to his own posts from the British side of the line. "61

As the Red River buffalo hunt usually rendezvoused at Pembina before and after the hunt, it gave Kittson an opportunity to purchase buffalo robes from the hunters before they returned north of the border. ${ }^{62}$ Even though the Red River hunters were selling peltries in American territory, it was still a violation of their contracts with the Hudson's Bay Company and they were technically breaking British law. ${ }^{63}$

As Kittson was not officially an employee of the AFC, the Americans were not in total violation of their secret agreement from 1833 with the Hudson's Bay Company. George Simpson treated Kittson as an independent, and attempted to destroy his business by acquiring an American trading license for an HBC employee who is only referred to as Fisher. Fisher set up a trading post right beside Kittson's, and would purchase the

${ }^{58}$ Clarence Rife, "Norman Kittson: A Fur Trader from Pembina,” Minnesota History 6 No. 3. (1925): 233234.

59 Jocelyn Willis, Boosters, Hustlers, and Speculators: Entrepreneurial Culture and the Rise of Minneapolis and St. Paul (Minneapolis: Minnesota State Historical Society, 2005), 25.

${ }^{60}$ Rife, 231.

${ }^{61}$ Ibid, 230.

62 Ibid.

${ }^{63}$ Fitzgerald, 212. 
hunters' goods at the same time as Kittson was during the 1845 season. ${ }^{64}$ As the HBC was a British company operating on American territory, Kittson decided to begin buying and selling furs north of the border as opposed to just below it as he had been before. This resulted in a significant row with Alexander Christie (Governor of Assiniboia) and developed into a trade war between Kittson and the HBC. ${ }^{65}$ The competition became so fierce that, at one point, Kittson persuaded the Metis residents at Pembina to petition the Governor of the new territory of Minnesota (Gov. Ramsay) to send a militia to the post to prevent the Red River Metis from hunting American buffalo. ${ }^{66}$ For the HBC, events along the border were starting to resemble the competition that had been so financially ruinous three decades previously.

Many of the more successful residents of Red River took advantage of the American outpost on a large scale. Initially, it was mostly successful younger traders like Peter Garrioch who were building their business between Red River and Pembina, but eventually even established traders like James Sinclair and Andrew McDermot were enticed to join after their other ventures were thwarted by the Company ${ }^{67}$ It is the more senior traders whose signatures are found at the bottom of the Memorial sent to the Colonial Office in 1846.

To enforce their exclusive rights, the HBC would capture and imprison traders that were caught selling peltries to the Americans. Coinciding with the decision to more strictly enforce their license was the arrival of the first "recorder" 68 to the settlement. In 1837, the Hudson's Bay Company requested a recorder from Canada as they believed the population of the settlement had swelled enough to justify one ${ }^{69}$ Unfortunately, the one they settled on was Adam Thom.

Adam Thom had a very poor reputation among native French speakers as a rampant francophobe. During his time practising law in Montreal, he was active in writing editorials criticizing the Anglo political leadership in the city and colony for their appeasement of the French population. Under a pseudonym, he penned what became known as the "Anti-Gallic Letters" that were published in the latter part of 1835 and early

${ }^{64}$ Rife, 234.

${ }^{65}$ Ibid, 237.

${ }^{66}$ Ibid.

${ }^{67}$ Irene Spry, “James Sinclair” Dictionary of Canadian Biography Online, Vol. VIII, 1985, http://www.biographi.ca/en/bio/sinclair_james_8E.html.

${ }^{68} \mathrm{~A}$ recorder was usually a barrister who would perform judicial functions if there were not an appointed judge in a community, as well as the duties of a magistrate. As there was no official judge in Red River, those functions fell to the recorder.

${ }^{69}$ Pelly to Glenley, Letter, 02/01/1837. 
$1836 .^{70}$ These letters are paranoid and conspiratorial, as illustrated by descriptions such as "The French faction is a deadening incubus on the spirit of commercial enterprise." ${ }^{.71} \mathrm{~A}$ recorder adjudicating disputes and criminal trials as a servant of the Company was always going to be distrusted by a significant portion of the Red River population, but Thom's history ensured that the French population of the settlement would view the court as completely prejudiced against them.

The American buffalo robe trade created an opportunity for the Metis and Country-born residents at Red River that did not exist before the 1840s. Circumventing the HBC license, by trading peltries with Kittson at Pembina, meant that a trader was not held hostage to the artificially low prices the HBC paid. It created an opportunity for the hunters, particularly the younger ones, to earn a living and gave them optimism for their future. As the previous section explained, the HBC monopoly on all goods and lack of upward mobility in the Company had removed a lot of hope for residents in the settlement before Kittson had built his post. Unfortunately, much of that hope was taken away by the strict enforcement of the HBC exclusive trade right and the arrival of an antiFrench recorder.

\section{The Legal Argument Takes Shape}

As the mid 1840s arrived, English and French communities in Red River had reached a boiling point in their animosity towards the HBC. In the period between James Sinclair's success in selling tallow in London and his failure the following year in convincing the Company to transport his goods, he composed a letter to the Governor and Committee of the Company in London in which he emphasized the population of the settlement being "materially dependent on a market being afforded for the proceeds of the chase." 72 The market being essential because the residents were "incapable of directing themselves to agricultural occupations." ${ }^{, 73}$ The letter was signed by several of the other principal settlers, but was never responded to by the company. ${ }^{74}$ This act of disrespect, coinciding with the company's refusal to transport his tallow, put James Sinclair into a leadership position for the legal battle that was to come.

\footnotetext{
${ }^{70}$ This was a tense time for politicians in Montreal and the Canadas at large. In 1837 two separate rebellions would break out in Upper and Lower Canada (modern day Ontario and Quebec) with the one in Quebec being significantly more intense. Anti-French sentiment in the colony was hardly restricted to Thom.

${ }^{71}$ Adam Thom, "Letter Addressed to His Excellency the Earl of Gosford, Governor-in-Chief of the Canadas" Montreal Herald, 30 ${ }^{\text {th }}$ September 1835.

72 Fitzgerald, 202.

${ }^{73}$ Ibid.

${ }^{74}$ Ibid.
} 
On August $25^{\text {th }} 1845$, Sinclair was told by the HBC that he would no longer be able to ship or receive goods on Company ships from York Factory. ${ }^{75}$ Four days later, he and many of the same principal residents from the previous letter composed a letter to Alexander Christie, the Governor of Assiniboia. In the letter, they claim that as natives of the country and half-breeds they have the right to hunt furs in Rupert's Land, and to sell to whomever is the highest bidder. They proceed to ask several questions of the Governor including:

Has a Half-breed, a settler, the right to hunt furs in this country?

Has a native of this country (not an Indian) the right to hunt furs?

Can a half-breed sell his furs to any person he pleases?

Is a half-breed obligated to sell his furs to the Company at any price the Company may think proper to give him?

With regard to trading or hunting furs, have the half-breeds, or natives of European origin, any rights or privileges over Europeans? ${ }^{76}$

In this letter, the authors are testing various legal arguments. They are determining if they are better off positioning themselves as half-breeds or native British subjects. Note how the last question they ask of Christie does not really distinguish between being a halfbreed or merely being born in Rupert's land of European stock. Also, note how none of the questions specifically refer to the resident's having Indian rights.

Christie's response to this letter is extremely important, as it is very similar to the ones that are to be seen later in official correspondence from the Company and the Colonial Office. Christie says:

Your first nine queries, as well as the body of your letter, are grounded on the supposition, that the half-breeds possess certain privileges over their fellow citizens who have not been born in the country. Now, as British subjects, the half-breeds have clearly the same rights in Scotland or in England as any person born in Great Britain, and your own sense of justice will at once see how unreasonable it would be to place an Englishman and Scotchman on a less favourable footing in Rupert's Land than yourselves. Your supposition further seems to draw a distinction between half-breeds and persons born in the country of European parentage, and to men of your intelligence I need not say that this distinction is still more unreasonable than the other. ${ }^{77}$

${ }^{75}$ As has already been discussed, this meant that he was unable to ship or receive goods at all legally. As York Factory was the only transport outlet that Red River residents had access to.

${ }^{76}$ Fitzgerald, 207.

Fitzgerald, 209. 
Generally speaking, it was the policy of the British Empire that there were two classes of men: British subjects and aboriginals. Aboriginals were infantilized by having their political and property rights restricted, but the government owed a certain obligation to them as they were considered to have rights to the soil. British subjects had political and property rights, ${ }^{78}$ and would have them in all corners of the Empire. Christie was expressing the opinion that one could not have both the rights of an aboriginal and of a British subject, it had to be one or the other. This opinion, as shall be seen, was shared by the Colonial administrators in London.

This response from Christie likely convinced the residents that they would have no luck petitioning the Colonial Office merely as British subjects, even if they did grow up in the country. Therefore, an additional tactic would be required if they were to petition the Colonial Office. Their desire for immediate change to the status quo would turn to desperation after the events of the following winter.

The Red River settlement was devastated by an influenza outbreak during the winter of 1845-1846, which was exacerbated by the same year's failure of the hunt and of the crops. ${ }^{79}$ As was discussed earlier, the hunt and subsistence farming complimented each other so that if one were to fail the other would make up for any losses. However, in 1846 both failed at a time that disease was ravaging their community. By May and June the influenza had turned into measles, killing approximately eight in every hundred people in St. Francois Xavier parish, and six in every hundred in St. Andrews. ${ }^{80}$ The settlement appears to have been consumed by fear, according to Alexander Ross "Hardly anything to be seen but the dead on their way to their last home, nothing to be heard but the tolling of bells, nothing talked of but the sick, the dying, and the dead. ${ }^{81}$ Gerhard Ens suggests that this mortality crisis must have had an effect on the free trade movement, as the population (particularly the younger generation) would have become increasingly desperate and the Company had lost whatever moral authority they had. ${ }^{82}$ It was that year, in 1846, that the residents of Red River sent their memorial and petition to London.

\section{The Memorial and Petition:}

${ }^{78}$ This is a massive oversimplification. Englishmen with the vote had the ability to vote for members of parliament that actually had authority over them. Canadians did not have a right to vote for Members of the British Parliament, who were still the final decision making body as far as administration of their colony was concerned. Therefore, the statement that all British subjects were equal is in actuality false. However, in this context it is meant that as British subjects there was no expectation of a paternalistic relationship between the authorities and the residents of Red River.

${ }^{79}$ Ens, 107.

${ }^{80}$ Ibid.

${ }^{81}$ Ibid, 109 .

${ }^{82}$ Ibid. 
In 1846 and $1847,{ }^{83}$ the residents of Red River sent a package of documents over to London to be presented before the Colonial Office. These included a memorial written in English and a petition written in French. The English document was signed by six prominent country-born and the French document was signed by over nine hundred metis. These documents were presented by A.K. Isbister (a London barrister of mixed ancestry originally born in Rupert's Land) to the Colonial Secretary's (Earl Grey's) office. Additionally, the writings of Thomas Simpson and Rev. Henry Beaver were included in which the Hudson's Bay Company is accused of crimes in its administration of Rupert's Land. These documents were as much political as they were legal.

Unlike their letter of the previous year, the memorialists argue that they have rights as aboriginals claiming that "even if (the charter) vests in the Company an exclusive right of trade to Hudson's Bay as against all other traders from Britain, none of its provisions are or can be binding on the natives to trade with the Company exclusively, or can prevent them from carrying their furs or other property out of the country to the best market." ${ }^{, 84}$ They complain that "...the natives, who are the original owners of the soil, have their energies and hopes completely paralyzed, and are doomed to starvation, in a land which is their own by birth and by descent." 85 The French petition also insists on their rights to the soil by proclaiming "Par le monople de HBC, les habitants indigenes ont la penible imposition de voir exportees taute les richesses de leur pays au profit exclusif de commercant etrangers." ${ }^{86}$ Asserting aboriginal rights over the company's charter relied on the legal understanding that the Proclamation of 1763 claimed all Indian land was held by the Indians until it was ceded by treaty. ${ }^{87}$ As the treaty making process had not yet started in the west, the argument suggested that the Company had no rights to impose an exclusive trade relationship on the original inhabitants of the soil.

The second half of the argument was that they were also British subjects. This was an important element as, although the residents of Red River wanted the aboriginal right to sell to whom they pleased, they did not want the handicaps that went along with being an

${ }^{83}$ The residents actually sent the same package over twice. The 1846 document only included six signatures from the French community, whereas the 1847 document included just under a thousand. The 1847 document package also omitted Isbister's report that framed the memorial and petition as well as his instructions. Otherwise the documents are basically identical, and the responses from the HBC and Colonial Office are to the initial 1846 document.

84 "Memorial and Petition" in Hudson's Bay Company (Red River Settlement), Copy of Memorial and Petitions from inhabitants of the Red River Settlement, complaining of the Government of the Hudson's Bay Company, and reports and correspondence on the subject of the memorial, (London: House of Commons Printer, 1849) p. 2-3. Peel 270.

85 Ibid.

${ }^{86}$ Ibid, 5.

${ }^{87}$ Editors of Encyclopaedia Britannica, "Proclamation of 1763 " Encyclopaedia of Britannica Online. Accessed April 1" st 2016. http://www.britannica.com/event/Proclamation-of-1763. 
Indian. This would have meant being treated like children by the $\mathrm{HBC}$ and the British government. This is why the French petition begins "Comme sujets Britanniques" 88 and why the English memorialists are "compelled to appeal to their Sovereign," 89 and hope

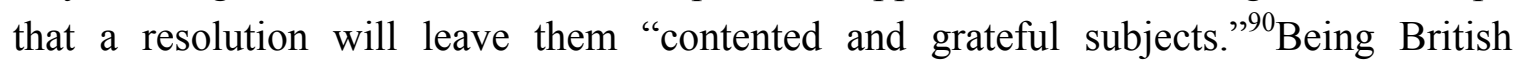
subjects meant that they could rely on a government "distinguished for its attachment to a liberal policy and the principles of commercial freedom" 91 in order to assist them in protecting their property rights.

The document attempts to intertwine aboriginal and British rights. The quote "the lives of the unoffending native race, who for no fault of their own, and for no reason that can be given, are deprived of their inheritance and their natural rights" ${ }^{\prime 92}$ is an excellent example. Inheritance refers to their aboriginal rights of the soil and 'natural rights' would have been understood to mean individual rights in the Lockian sense that applied to all British subjects. This novel legal argument would not be accepted by the Colonial Office.

Above it was noted that the document was as much political as it was legal, as it was probably expected to be read beyond merely the clerks of the Colonial Office. Therefore, the document at certain points appears intended to mislead. The word "natives" is used to refer to various groups of people. At times it appears to refer exclusively to the Indians when it accuses the Company of:

"With a view of keeping the natives in a state of utter dependence, and of perpetuating the wandering and precarious life of a hunter, on which they erroneously consider the existence of the fur trade to depend, they have permitted generation after generation of the hapless race consigned to their care to pass their lives in the darkest heathenism." 93

Given the prominence of Anglicanism in Fort Garry, it is unlikely that the memorialists believed that they were passing their lives in "the darkest heathenism". However, on other occasions the term "natives" obviously refers to the mixed bloods.

"... many of the more enterprising of the natives have formed a resolution to export their own produce and import their own supplies, independent of the Company.",94

This excerpt likely refers to James Sinclair's attempt to sell tallow in London. Accordingly, the document uses the term "natives" when it is the most suitable for the

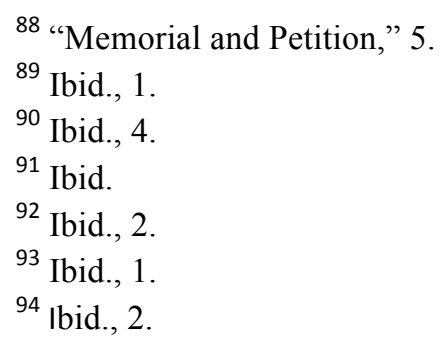


memorialists' purposes. It is used so that the reader is led to believe that the Company is oppressing the original owners of the soil as opposed to merely enforcing the law against British subjects. Therefore, it is consistent with an instrumental approach to ethnicity or nationalism.

The memorial and petition portray the residents of Red River as aboriginals with rights to the soil and as British subjects. It is important to understand why both elements of this argument would have been included. As British subjects, Christie had informed them (in his letter of September 1845) that British law prevented them from trafficking in furs or participating in any trade that infringed upon the rights of the exclusive trade license. Therefore, in order to circumvent the company's monopoly, the residents had to have a right that superseded the Company's right. In this case, the rights to the soil through their mother's aboriginal ancestry. However, merely asserting themselves as aboriginals would not have the desired effect, as if they were considered aboriginal they would likely be infantilized by the British government in the same way that the Indians were. In the eyes of London, the paternal influence of the Hudson's Bay Company would seem beneficial in order to civilize them. Therefore, the purpose of the argument was to allow them to break the monopoly as aboriginals but to be considered mature enough to handle the free commerce they desired.

\section{The Response from the Colonial Office and The Hudson's Bay Company:}

The Colonial Office, after receiving the Memorial and Petition, launched an investigation into the accusations that had been made. ${ }^{95}$ Part of that investigation included directing the Governor of the Hudson's Bay Company (Pelly) to reply to the charges laid against his company. In his report, Pelly is quick to explain the deception employed when using the term "natives". ${ }^{96}$ He refuses to acknowledge that the memorialists and petitioners are "natives", and only utilizes that term when referring to Indians. This emphasizes that the mixed blood residents of Red River do not have any aboriginal rights to the soil, according to Pelly's interpretation. ${ }^{97}$ As Pelly explains:

"The circumstances of their being born in the country may entitle them to call themselves natives, but it neither conveys to them any privileges belonging or supposed to belong to the aboriginal inhabitants. Nor does it divest them of the character of British subjects, all of whom are precluded by the Company's charter from trafficking in furs within the limits

${ }^{95}$ Apart from what has been discussed, the Memorial and Petition accused the HBC of a litany of crimes ranging from wrongful convictions to being indirectly responsible for cannibalism. The scale and depravity of the crimes accused would not have failed to get the Office's attention. In fairness to the HBC, it is unlikely they were responsible (however indirectly) for any acts of cannibalism.

${ }^{96}$ J.H. Pelly, "Pelly’s Report to Earl Grey.” Letter, 24 April 1847. Peel 270.

${ }^{97}$ Ibid. 
without a license from the company, and the Red River settlers are additionally bound, by the covenants under which they hold their lands, to abstain from such traffic." 98

He also explains that the license to exclusive trade is in the memorialist's best interest because:

"If they understood their true interest they would abandon the chase and apply themselves solely to agriculture, which would abundantly supply them with the means of living comfortably. They would thus lead a life... of more civilizing pursuits."99

Pelly does not argue that the residents of Red River were not British subjects, but refuses to acknowledge any aboriginal right that would supersede his Company's charter or the rights of any other British subject in Rupert's Land.

Pelly also considers the Company's charter, and its enforcement, as the best way to protect against American expansionism in the west. He argues that:

"The Company has been compelled to adopt this expedient in self-defence, there being no alternative but to surrender the trade in that quarter entirely to American interlopers and their confederates the leaders of the half-breeds at the Red River settlement."100

Thus, he accuses the Red River residents of being treasonous. A.K. Isbister, who responds to Pelly's report on behalf of the memorialists and petitioners, returns the favour by emphasizing the patriotism of the Red River residents and suggests that the Company would sell all of Rupert's Land to the Americans to make a profit. ${ }^{101}$ Isbister's idea of the Metis being a British bulwark against the HBC's treasonous ways was a new addition to the concept of Metis identity being presented to the Colonial Office.

The Colonial Office asked the Governor General of Canada, Lord Elgin, to dispatch an independent party to Red River in order to ascertain the validity of the claims made against the Company. Elgin reported to Grey:

"...the result of the inquiries I have made is highly favourable to the Company, and that it has left on my mind the impression that the authority with which they exercise over the

98 Ibid.

99 Ibid.

100 Ibid.

${ }^{101}$ A.K. Isbister, Isbister to Hawes Responding to Pelly's Report. Letter. June $21^{\text {st }} 1847$, in Hudson's Bay Company (Red River Settlement), Copy of Memorial and Petitions from inhabitants of the Red River Settlement, complaining of the Government of the Hudson's Bay Company, and reports and correspondence on the subject of the memorialhttps://eclass.srv.ualberta.ca/pluginfile.php/2635068/mod_resource/content/1/1849-026015p1to120.pdf 
vast and inhospitable region subject to their jurisdiction, is on the whole very advantageous to the Indians. "102

However, Elgin did suggest:

"At the same time I think it is to be regretted that a jurisdiction so extensive and peculiar, exercised by British subjects at such a distance, and so far beyond the control of public opinion should be so entirely removed from the surveillance of the British government.... (A presence) will exercise over the agents of the Company a salutary influence, while it will at the same time supply the channel through which accurate information respecting the proceedings of the Company may reach Her Majesty's Government, and useful advice, if necessary, be tendered in return.",103

Just like Pelly, Elgin acknowledged the Red River residents' rights as British subjects but not as aboriginals. Therefore, the residents were compelled to follow the obligations of being British subjects as well, namely complying with the HBC's charter.

After considering the complaints made in the memorial and petition, as well as the reports from Elgin and Pelly, Earl Grey determined that the Charter was legal and that the accusations made against the Company were groundless. ${ }^{104}$ He agreed with Pelly's and Elgin's argument that the residents of Red River were British subjects, with the same rights and obligations as a Scot or an Englishman. By dispatching with the arguments and accusations made in the memorial and petition, the British government refused to acknowledge any uniqueness to Metis identity. It would take two decades, annexation to Canada, and a small insurrection for the Red River Metis to obtain any legal rights (or benefits) beyond those of merely British subjects.

\section{Aftermath:}

As far as free trade went, the debate over rights was made moot by 1849 . In that year, a Metis named Guillaume Sayer was charged and convicted of smuggling furs. ${ }^{105}$

${ }^{102}$ Lord Elgin, Dispatch from Governor General of Canada Lord Elgin to Colonial Secretary Earl Grey, 6 June 1848, in Hudson's Bay Company (Red River Settlement), Copy of Memorial and Petitions from inhabitants of the Red River Settlement, complaining of the Government of the Hudson's Bay Company, and reports and correspondence on the subject of the memorial.

https://eclass.srv.ualberta.ca/pluginfile.php/2635068/mod_resource/content/1/1849-026015-p1 to120.pdf

${ }^{103}$ Ibid.

${ }^{104}$ B. Hawes (Colonial Undersecretary) to Sir J.H. Pelly, Bart. Letter of 5 June 1847, in Hudson's Bay Company (Red River Settlement), Copy of Memorial and Petitions from inhabitants of the Red River Settlement, complaining of the Government of the Hudson's Bay Company, and reports and correspondence on the subject of the memorial.

https://eclass.srv.ualberta.ca/pluginfile.php/2635068/mod_resource/content/1/1849-026015-p1 to120.pdf

${ }^{105}$ W.L. Morton, "Sayer, Pierre-Guillaume" Dictionary of Canadian Biography (Toronto: University of Toronto Press, Vol. VII, 2003, Accessed March 29 ${ }^{\text {th }}, 2016$ ). http://www.biographi.ca/en/bio/sayer_pierre_guillaume_7E.html. 
However, the jury let him off with no sentence as the courthouse was surrounded by several hundred armed Metis residents. Once the sentence was read, the Metis understood that they would no longer be punished for trading furs outside of the company. Therefore, where elite lawyers and unique legal arguments about identity had failed, several hundred armed Metis standing menacingly outside a courthouse succeeded.

The campaign to eliminate the Charter did not end there, however. In London, A.K. Isbister continued to lobby on the residents' behalf for another decade before the Charter was officially retired. Accounts and arguments were published in London periodicals complaining of the tyranny of the $\mathrm{HBC}$, and tended to focus on the residents' rights as aboriginals rather than their rights as British subjects. Two more prominent examples are James Fitzgerald's 1849 examination of the HBC's administration of the settlement ${ }^{106}$, and a series of articles written for the Colonial Intelligencer of the Aborigine Protection Society in London in the 1850s. ${ }^{107}$ One notable exception to this trend was the "Hudson's Bay Company versus Magna Carta" series that was published by the Liverpool Financial Reform Association in 1857. This series focused on the resident's rights to commercial freedom as British Subjects more than their aboriginal rights of soil. ${ }^{108}$ The Liverpool Financial Reform Association argued that "grants of monopolies are against the ancient and fundamental laws of the kingdom" "109, and presented the Red River residents" arguments in the context of the trade history of the British Empire. They argued that as the Empire had virtuously done away with monopolies and tariffs that the HBC's Charter was a nefarious anachronism. ${ }^{110}$ However, apart from the Liverpool Financial Reform Association, the plight of the Red River settlers was portrayed in London as aboriginal residents being deprived of their land rights rather than British subjects being deprived of their commercial rights.

\section{Conclusions:}

Red River Metis identity in the first half of the nineteenth century was not primordial, but developed instrumentally as a means to further their interests. The idea of being both natives, with rights to the soil, and British subjects, with commercial and political rights, was a legal and political argument that developed as a means to have the Hudson's Bay Company's exclusive trade charter rescinded. During the Pemmican Wars that preceded the merger period, the mixed blood communities fought on both sides with loyalties being determined by which of the two companies they were associated with. It was not

\footnotetext{
${ }^{106}$ Fitzgerald, 205-206.

${ }^{107}$ Aborigine's Protection Society, “The Red River Settlement and the Hudson's Bay Company”, Volume II of the Colonial Intelligencer, 1848. 35-47. Peel 248.

${ }^{108}$ Gladstone, 4.

${ }^{109}$ Ibid., cover page.

${ }^{110}$ Ibid., 8.
} 
until after the merger, when opposition to the $\mathrm{HBC}$ was common to both parties, that any sense of common identity emerged.

Linkages between the metis and country-born communities were created after 1821, when large-scale hunting parties were required to hunt buffalo. The cooperation and structure of these bi-annual expeditions fostered relationships and ties of community between the two primary mixed blood groups. Their shared dependence on the HBC meant that they began to share grievances after the Company was unwilling to purchase all of their pemmican after 1832, and continued when other avenues of trade began to be closed off. Both groups struggled with agriculture and continued to depend on the buffalo hunt as their primary employment throughout this period, although it continued to bring them into conflict with the HBC. As the hiring standards and upper officer corps of the Company began to exclude local mixed-bloods, both communities felt discriminated against due to their Mothers' aboriginal heritage. Red River residents grew concerned that their children would have no economic opportunity in the settlement. Norman Kittson's fur trading post in Pembina created hope that the Red River residents would have an economic future hunting buffalo. However, the HBC's concern over how competition would affect their shareholders' investment, as it had during the first two decades of the nineteenth century, ensured that the Company would zealously guard their rights to exclusive trade and prevent the settlement's residents from trading with Kittson. As the Company continued to tighten the vise on any enterprise originating in the settlement, such as Sinclair's tallow interest, the residents had to develop a creative legal argument to convince the Colonial Office to rescind the Company's charter. It was the commercial interests of the settlement's elites, combined with the desperation felt throughout the settlement, that led to the 1846 Memorial and Petition.

The Memorial and Petition that the residents sent to London is the first time the argument is made that the mixed-blood residents of Red River have both rights to the soil, as aboriginals through their Mothers, and the rights of British subjects through their fathers. The unique situation on the north-west plains required this argument, for British law prevented British subjects from being able to trade outside the Company, but being an Indian would have ensured that the Colonial Office would have seen value in the paternal influence of the HBC and held up the Company's rights under their charter. Therefore, the genesis of their identity as both British subjects and as aboriginals was related to a legal argument in an attempt to undermine the Company's charter. This is consistent with Gerhard Ens' theory that Metis ethnogenesis was instrumental.

Assessing Metis ethnogenesis as instrumental does not make it any less genuine. Eric Hobsbawn, in the introduction to his collection "The Invention of Tradition", comments: 
"We should not be misled by a curious, but understandable, paradox; modern nations and all their impedimenta generally claim to be the opposite of novel, namely rooted in the remotest antiquity, and the opposite of constructed, namely human communities so 'natural' as to require no definition other than self-assertion. Whatever the historic or other continuities embedded in the modern concept of 'France' and 'the French'- and which nobody would seek to deny- these very concepts themselves must include a constructed or 'invented' component. And just because so much of what subjectively makes up the modern 'nation' consists of such constructs or suitably tailored discourse (such as 'national history'), the national phenomenon cannot be adequately investigated without careful attention to the 'invention of tradition." 111

Accordingly, all tradition and identity is to some degree invented. The fact that the Metis tradition of being both aboriginal and white was a legal and political argument intended to win a political battle, does not change the reality that modern Metis identify with both heritages.

\section{Bibliography}

Aborigine's Protection Society, “The Red River Settlement and the Hudson's Bay Company”, Colonial Intelligencer, Vol. II (1848). First accessed through Peel's Prairie Archives at the University of Alberta, March 13 ${ }^{\text {th }}, 2016$. Peel 248.

Bindon, Kathryn. “Thom, Adam,” Dictionary of Canadian Biography Online. 2003. Accessed March $18^{\text {th }} 2016$. http://www.biographi.ca/en/bio/thom adam 11E.html.

Clark, Leland. "The Place of the Metis within the agricultural economy of Red River during the 1840's and the 1850's," Canadian Journal of Native Studies, Volume III (1983).

Colpitts, George. "Provisioning the HBC: Market Economies in the British Buffalo Commons in the Early Nineteenth Century," The Western Historical Quarterly 43, no. 2.

\footnotetext{
${ }^{111}$ Eric Hobsbawn, The Invention of Tradition_(Cambridge: Cambridge University Press, 1983), 14.
} 
Cowie, Isaac. The minutes of the Council of the Northern Department of Rupert's Land, 1830 to 1843, Bismarck North Dakota: State Historical Society of North Dakota, 1915. First accessed through Peel's Prairie Archives at the University of Alberta, March $20^{\text {th }}, 2016$.

Elgin, Lord. Dispatch to Colonial Secretary Earl Grey of 6 June 1848. “Hudson's Bay Company (Red River Settlement), Copy of Memorial and Petitions from inhabitants of the Red River Settlement, complaining of the Government of the Hudson's Bay Company, and reports and correspondence on the subject of the memorial." Government Documents, London: House of Commons Printer, 1849. First accessed on Gerhard Ens' University of Alberta eclass site on February $18^{\text {th }}$, 2016. Accessible through Peel's Prairie Archives at the University of Alberta. Peel 263.

Encyclopaedia Britannica. "Proclamation of 1763". Encyclopaedia of Britannica Online, Accessed April 1 ${ }^{\text {st }}$ 2016. http://www.britannica.com/event/Proclamation-of-1763.

Ens, Gerhard. Homeland to Hinterland, Toronto: University of Toronto Press, 1996.

Ens, Gerhard, and Sawchuk, Joe. From New Peoples to New Nations. Toronto: University of Toronto Press, 2016.

Easterbrook, W.T., Aitkin, Hugh. Canadian Economic History, Toronto: University of Toronto Press, 1988.

Fitzgerald, James E. An Examination of the Charter and Proceedings of the Hudson's Bay Company, with Reference to the Grant of Vancouver's Island. London: Trelawney and Saunders, 1849. First accessed through Peel's Prairie Archives at the University of Alberta, March 13 ${ }^{\text {th }}, 2016$. Peel 262.

Gladstone, Robertson. "The Hudson's Bay Company versus Magna Carta, and the British People”, Pamphlet, Liverpool: Financial Reform Association, 1857. First accessed through Peel's Prairie Archives at the University of Alberta, March 10 $0^{\text {th }}, 2016$. Peel 344.

Hawes, B. Letter to Sir J.H. Pelly of June $5^{\text {th }}$ 1847. "Hudson's Bay Company (Red River Settlement), Copy of Memorial and Petitions from inhabitants of the Red River Settlement, complaining of the Government of the Hudson's Bay Company, and reports and correspondence on the subject of the memorial." Government Documents, London: House of Commons Printer, 1849. First accessed on Gerhard Ens' University of Alberta eclass site on February $18^{\text {th }}, 2016$. Accessible through Peel's Prairie Archives at the University of Alberta. Peel 263. 
Hobsbawn, Eric. The Invention of Tradition, Cambridge: Cambridge University Press, 1983.

Hogue, Michael. Metis and The Medicine Line, Chapel Hill: University of North Carolina Press, 2015.

Isbister, A.K. Letter to Hawes of June $21^{\text {st }} 1847$. "Hudson's Bay Company (Red River Settlement), Copy of Memorial and Petitions from inhabitants of the Red River Settlement, complaining of the Government of the Hudson's Bay Company, and reports and correspondence on the subject of the memorial. " Government Document, London: House of Commons Printer, 1849. First accessed through Peel's Prairie Province Archives at the University of Albert, March 11 ${ }^{\text {th }}, 2016$. Peel 263.

Memorialists and Petitioners of Red River. Memorial and Petition. "Hudson's Bay Company (Red River Settlement), Copy of Memorial and Petitions from inhabitants of the Red River Settlement, complaining of the Government of the Hudson's Bay Company, and reports and correspondence on the subject of the memorial." London: House of Commons Printer, 1849. First accessed on Gerhard Ens' University of Alberta eclass site on February $18^{\text {th }}, 2016$. Accessible through Peel's Prairie Archives at the University of Alberta. Peel 263.

Morton, W.L. "Sayer, Pierre-Guillaume", Dictionary of Canadian Biography Online. 2003. Accessed March $29^{\text {th }} 2016$. http://www.biographi.ca/en/bio/sayer pierre guillaume 7E.html.

Pelly, James. Letter to Lords of Privy Council on Trade of Feb. $7^{\text {th }}$, 1838. First Accessed through Peel's Prairie Archives at the University of Alberta, March $12^{\text {th }}, 2016$. Peel 210.

Pelly, James. Letter to Lord Glenley of Feb. $10^{\text {th }}, 1837$. Letter. First Accessed through Peel's Prairie Archives at the University of Alberta, March 12 $2^{\text {th }}, 2016$. Peel 210.

Pelly, James. Report to Earl Grey of April $24^{\text {th }}, 1847$. “Hudson's Bay Company (Red River Settlement), Copy of Memorial and Petitions from inhabitants of the Red River Settlement, complaining of the Government of the Hudson's Bay Company, and reports and correspondence on the subject of the memorial. " Government Documents, London: House of Commons Printer, 1849. First accessed on Gerhard Ens' University of Alberta eclass site on February $18^{\text {th }}, 2016$. Accessible in Peel Prairie Archives at the University of Alberta. Peel 263.

Rife, Clarence, "Norman Kittson: A Fur Trader from Pembina", Minnesota History, Vol. 6, No. 3 (1925). 
Spry, Irene. "Sinclair, James". Dictionary of Canadian Biography Online. Accessed March $18^{\text {th }}$ 2016. http://www.biographi.ca/en/bio/sinclair_james_8E.html.

Thom, Adam, Letter Addressed to His Excellency the Earl of Gosford, Governor-inChief of the Canadas. "Montreal Herald". $30^{\text {th }}$ September 1835. First Accessed through Peel Prairie Archives at the University of Alberta, March 18 ${ }^{\text {th }}, 2016$.

Willis, Jocelyn. Boosters, Hustlers, and Speculators: Entrepreneurial Culture and the Rise of Minneapolis and St. Paul, Minneapolis: Minnesota State Historical Society, 2005. 